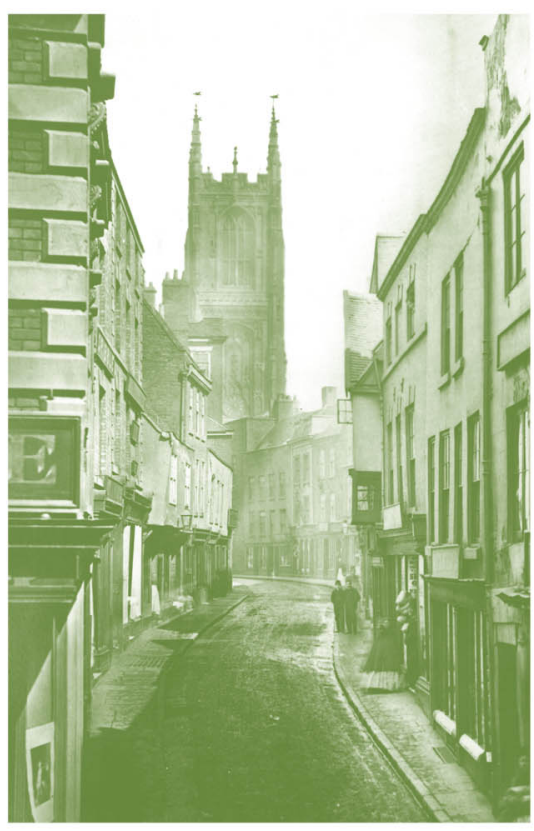

\title{
WRITING
}

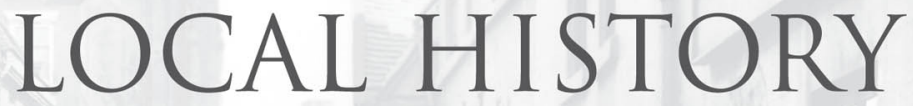

John Beckett 
WRITING LOCAL HISTORY

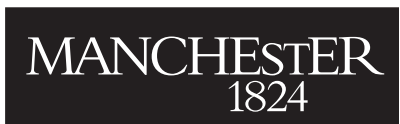

Manchester University Press 
Also available

The Scottish family tree detective: tracing your ancestors in Scotland Rosemary Bigwood

The family tree detective: tracing your ancestors in England and Wales Colin D. Rogers

The Irish family tree detective: tracing your ancestors in Ireland Francis Dowling (forthcoming) 


\section{Writing local history}

John Beckett

MANCHESTER UNIVERSITY PRESS

Manchester and New York

distributed exclusively in the USA by Palgrave 
The right of John Beckett to be identified as the author of this work has been asserted by him in accordance with the Copyright, Designs and Patents Act I988.

Published by Manchester University Press Oxford Road, Manchester MI3 9 NR, UK and Room 400, I75 Fifth Avenue, New York, NY Iooı,, USA www.manchesteruniversitypress.co.uk

Distributed exclusively in the USA by Palgrave, I75 Fifth Avenue, New York, NY IOOIo, USA

Distributed exclusively in Canada by

UBC Press, University of British Columbia, 2029 West Mall, Vancouver, BC, Canada V6T IZ2

British Library Cataloguing-in-Publication Data

A catalogue record for this book is available from the British Library

Library of Congress Cataloging-in-Publication Data applied for

ISBN 978 O 7I90 29509 hardback

ISBN 9780719076602 paperback

First published 2007

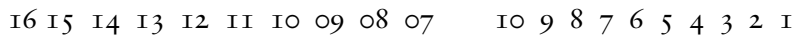

Typeset in Sabon 10.25/I2 pt by Servis Filmsetting Ltd, Manchester

Printed in Great Britain

by Bell \& Bain Ltd, Glasgow 